\title{
ISOLATION AND IDENTIFICATION OF HALOPHILIC BACTERIA PRODUCING EXOPOLYSACCHARIDES FROM WHEY AND MILK PERMEATE
}

Amal $^{\star}$ A. Hegazi, El-Nawawy M.A., Ali A.A. and El-Samragy Y.A.

Food Sci. Dept., Fac. of Agric., Ain Shams Univ., P.O. Box 68, Hadayek Shoubra 11241, Cairo, Egypt

*Corresponding author: amal hegazy@agr.asu.edu.eg

Received 10 May, 2019

Accepted 9 June, 2019

\section{ABSTRACT}

The aim of this research was to study the utilization ability of the salt whey and milk permeate to produce exopolysaccharides (EPSs) from halophilic bacteria. Where cheese whey is simultaneously an effluent with nutritional value and a strong organic and saline content. However, it is drained in the sewers, the EPSs are highly heterogeneous polymers produced by different species of bacteria and have recently been attracting considerable attention from biotechnologists because of their potential applications in many fields. Thus, we have isolated some halophilic bacteria that showed the ability to produce EPS from whey and milk permeate. A total of 46 strains of moderately halophilic bacteria were isolated from two types of samples. The first type was dairy samples (Baramily cheese whey and mish cheese), while the second type was water samples (salty lake water and its sediments) of Wadi El-Natrun Valley (lakes Hamra, UmRisha, and Baida), Beheira Governorate, Egypt. From isolated strains there are twelve strains were having the ability to produce exopolysaccharides but only seven strains can produce EPS from whey and milk permeate. The growth conditions i.e. concentrations of $\mathrm{NaCl}, \mathrm{pH}$ value and different incubation temperature, of isolates were determined. The effect of these conditions on the production of EPS was investigated. The obtained results indicated that the optimum conditions for the production of EPS by these strains were $10 \% \mathrm{NaCl}, \mathrm{pH} 7$ and the optimum incubation temperature was $37^{\circ} \mathrm{C}$. Three strains showed the highest production of exopolysaccharides. These strains were identified using two methods the first method was biolog system and the second one was $16 \mathrm{~S}$ rRNA sequence analysis method. It could be identified as Alteribacillus bidgolensis and Bacillus licheniformis. Alteribacillus bidgolensis (strain $\mathrm{P} 4 \mathrm{~B}$ ) produced the highest amount of EPS $(52 \mathrm{~g} / \mathrm{L})$ from whey followed by Bacillus licheniformis (DSM 13) (42 g/L), while the highest amount of EPS produced from milk permeate was $(43 \mathrm{~g} / \mathrm{L})$ by Alteribacillus bidgolensis (strain $\mathrm{P} 4 \mathrm{~B}$ ) followed by Bacillus licheniformis (DSM 13) (36 g/L).

Keywords: Halophilic bacteria, Exopolysaccharides, Whey, Milk permeate, Alteribacillus bidgolensis, Bacillus licheniformis.

\section{INTRODUCTION}

Cheese whey is the most polluted byproduct induced in the production of cheese. It can cause an overabundance of oxygen utilization, toxicity, impermeabilization, etc.., in the receiving environment conditions. The volume of effluents delivered in the cheese production industry has expanded with the expansion in cheese creation. World production of whey is about $2 \times 10^{8}$ tons per annum, containing $\sim 9 \times 10^{6}$ tons of lactose and $1.4 \times 10^{6}$ tons of whey proteins (Fox et al 2017).

Milk permeate got from the ultrafiltration of milk is free from proteins, however, contains the other dissolvable constituents of milk. The dairy industry is effectively looking for approaches to use this byproduct which will help increment the estimation of dairy industry. These byproducts still contain valuable components, i.e. amino acids, lactose, minerals and even little amounts of protein that could be utilized for the production of some valuable products such as fermented products, sports drinks, snacks, infant's food etc. 
Several types of bacteria such Xanthomonas campestris can produce extracellular polysaccharides (EPS). EPS are bound to the cell surface and after that release into the grown media. Microbial EPS offer a potential new wellspring of useful biopolymers for industrial, pharmaceutical medicinal applications and food. It can be used as thickeners, suspending operators, or gelling agents to improve the quality and structure of food (Morris and Harding 2009).

Halophilic and halotolerant organisms were found in each of the three species of life: Archaea, Bacteria, and Eukarya. Halophiles are classified into three groups according to salt needs, slightly halophiles $(2-5 \% \mathrm{NaCl})$, moderately halophiles $(5-20 \% \mathrm{NaCl})$ and extremely halophiles (20-30 $\% \mathrm{NaCl}$ ) while strains live in $0-5 \%$ saltiness are considered halotolerant microorganisms (Abd Samad et al 2017). Some halophilic microorganisms can produce exopolysaccharides (Bejar et al 1998). Their EPS's are of extraordinary physical properties, e.g. the capacity to emulsify at acidic $\mathrm{pH}$ (Martinez-Checa et al 1996). Their chemical and physical structures are valuable in different industrial fields when using as thickening and binding agent (Tombs and Harding 1998).

Wadi El Natrun, Beheira Governorate, Egypt, is a valley consists of seven substantial, basic, hypersaline, thalassic lakes and various fleeting pools. Salinities extending from 1.5 to $5.0 \mathrm{M} \mathrm{NaCl}$, $\mathrm{pH}$ estimations of somewhere in the range of 8.5 and 11 and temperatures of up to $50^{\circ} \mathrm{C}$ make Wadi El-Natrun lakes great environments for the confinement of extremophiles. A rich microbial assorted variety exists in both the waters and sediments of Wadi El Natrun lakes (Mesbah et al 2007).

The objective of this study was to isolate some halophilic bacteria to select those that maximize utilization of lactose as a substrate to produce exopolysaccharides from salt whey and milk permeate.

\section{MATERIALS AND METHODS}

\section{Materials}

\section{1- Samples collection and handling}

The halophilic strains were isolated from two types of samples. The first type was dairy samples (Baramily cheese whey and mish cheese), while the second type was water samples (salty lake water and its sediments) collected during July 2016 from three lakes, i.e Hamra, UmRisha, and Baida, of Wadi El-Natrun.

\section{2- Whey and milk permeate}

Sweet whey and milk permeate samples were obtained from Arabian Food Industries Company (Domty), $6^{\text {th }}$ October City, Giza, Egypt.

\section{Methods}

\section{1- Determination of salt content}

The salt content of the brine was determined according to Mohr titration (James, 1995).

\section{2- Screening test for exopolysaccharide pro- duction}

Screening test was carried out on Halobacteria medium (372) was prepared according to (German Collection of Microorganisms and Cell Cultures) DSMZ GmbH catalog 2007, whey agar and milk permeate agar media (with $10 \% \mathrm{NaCl}$ ). The isolated strains were plated and incubated under aerobic conditions at $37^{\circ} \mathrm{C}$ for 3- 4 days. At the end of incubation period, mucoid of colonies was determined by visual appearance, while it's ropiness was evaluated by touching them using a sterile inoculation loop (Welman et al 2003) and confirmed by ethanol precipitation method (RuasMadiedo and de los Reyes-Gavilan 2005).

\section{3- Identification of selected strains}

The strains were identified using physiological, biochemical tests (Biolog, 2013). and 16S rRNA sequence analysis methods as following:

- DNA (Deoxyribonucleic acid) was extracted using protocol of GeneJet genomic DNA purification Kit (Thermo K0721)

- PCR (Polymerase Chain Reaction) was made using Maxima Hot Start PCR Master Mix (Thermo K1051)

- PCR cleanup was made to the PCR product using Gene JET TM PCR Purification Kit (Thermo K0701)

- Finally sequencing to the PCR product was made on GATC Company by use ABI 3730xl DNA sequencer by using forward and reverse primers.

\section{RESULTS AND DISCUSSION}

\section{1- Characterization of isolated strains}

Data presented in Table (1) indicate the sampling sites, types, $\mathrm{pH}$, sodium chloride concentrations (\%) and distribution of halophilic isolates. It could be noticed that the water of lakes Baida and 

from whey and milk permeate

UmRisha are similar and they greatly differ from that of Lake Hamra. This result agrees with those obtained by Mesbah et al (2007). The distribution of the isolated halophilic bacteria grown on halo- bacteria medium (DSMZ M 372) using 15 and $20 \%$ $\mathrm{NaCl}$ as well as those grown in whey and milk permeate and production of exopolysaccharides is illustrated in Fig. (1).

Table 1. Samples sites, types, $\mathrm{pH}, \mathrm{NaCl}(\%)$ and distribution of halophilic isolates

\begin{tabular}{|c|c|c|c|c|}
\hline $\begin{array}{c}\text { Sampling } \\
\text { site }\end{array}$ & Sample type & $\mathbf{p H}^{*}$ & $\begin{array}{c}\mathbf{N a C l}(\% \\
\mathbf{w} / \mathbf{v})\end{array}$ & $\begin{array}{c}\text { Total number } \\
\text { of isolates }\end{array}$ \\
\hline Hamra & $\begin{array}{c}\text { Salty water } \\
\text { Salty sediments } \\
\text { Salty water } \\
\text { Salt } \\
\text { UmRisha }\end{array}$ & 8.5 & 10 & 11 \\
Baida & $\begin{array}{c}\text { Salty water } \\
\text { Salt }\end{array}$ & 9.8 & 29.1 & 2 \\
Whey & Baramily whey & 4.5 & 13 & 9 \\
Mish & Mish cheese & 4.1 & 8.2 & 3 \\
\hline
\end{tabular}

${ }^{*} \mathrm{pH}$ was measured at $25^{\circ} \mathrm{C}$

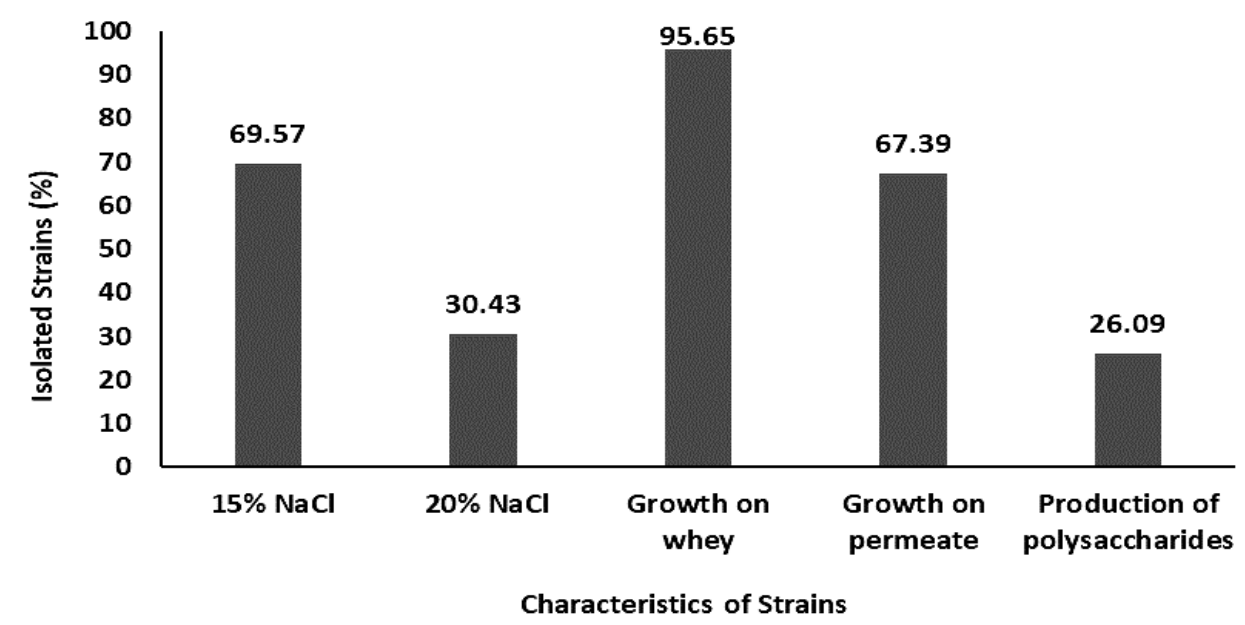

Fig. 1. Distribution of isolated strains at different growth conditions

The total number of isolated strains were 46 strains with identification numbers (1: 46). As shown in Fig. (1) it could be noticed that there are seven strains have the ability to grow on whey or milk permeate producing polysaccharides. Those strains were identified under numbers were 16, 36, 37, 39, 41, 44 and 45 . The selected strains were used for further research work while the other strains that couldn't grow on salted whey and/or permeate were discarded.

\section{2- Characterization of selected strains}

Fig. (2) indicates that the strains number 37 , 39,41 and 44 grown from 0 to $20 \%$ of $\mathrm{NaCl}$ with optimum concentration at concentration of $5 \%$ $\mathrm{NaCl}$ except strain No. 44 was $10 \% \mathrm{NaCl}$ its optimum. The growth range of $\mathrm{NaCl}$ for the strains No. 16 and 36 were from 5 to $20 \%$ with optimum concentration $10,15 \% \mathrm{NaCl}$, respectively. While the optimum salt concentration for the strain No. 45 was $15 \%$ and growth range was from 0 to $15 \%$ $\mathrm{NaCl}$. 
Data illustrated on Fig. (3) shows that $\mathrm{pH} 7$ was optimum for growth of all strains except strains strain No. 36 and 44 where the optimum $\mathrm{pH}$ for them was 8 after $96 \mathrm{hr}$ of incubation. The $\mathrm{pH}$ of the growth medium ranged from 5 to 9 for strains No. 37, 39,41 and 44. While it was from $\mathrm{pH} 6$ to 9 for the other strains, i. e No. 16,36 and 45.
The effect of the growth temperature was illustrated in Fig. (4) where the temperature range for all strains was from $25 \stackrel{\circ}{\circ}$ to $45^{\circ} \mathrm{C}$ and the optimum growth temperature was $37^{\circ} \mathrm{C}$ for the strains No. 16,37 and 41 , and $30 \stackrel{\circ}{C}$ for the strains No. $36,39,44$ and 45.

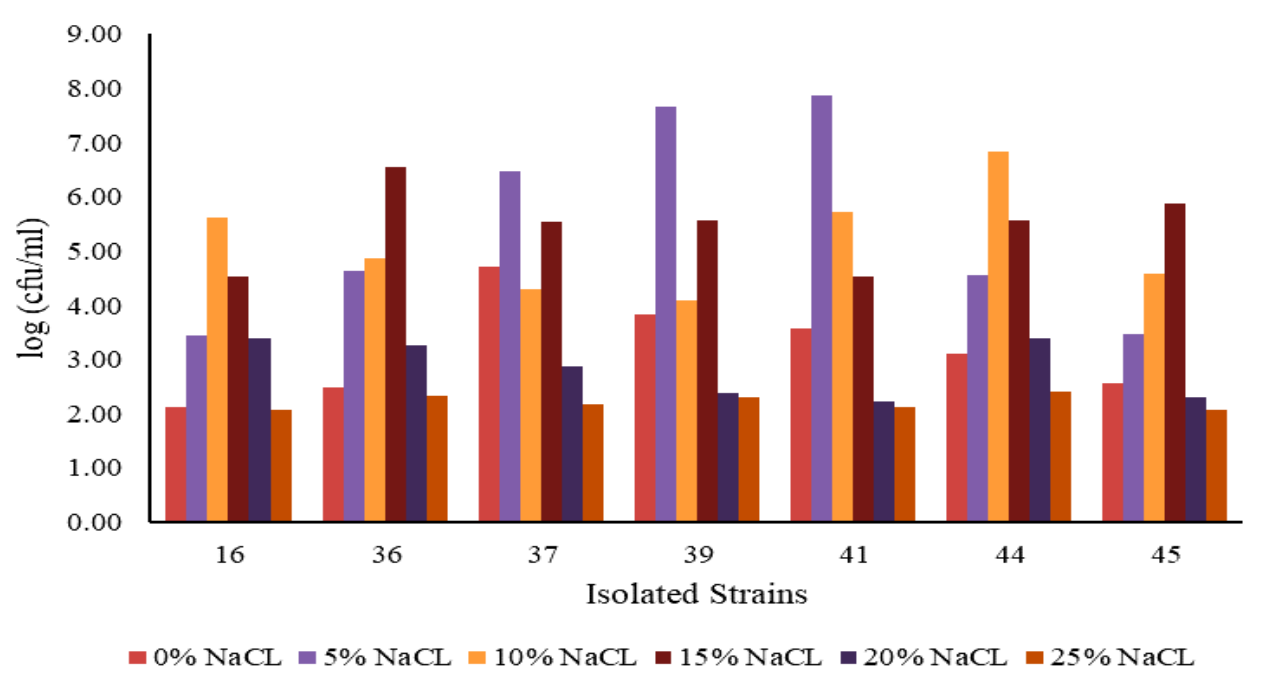

Fig. 2. Viable bacterial count of selected isolates at different concentrations of $\mathrm{NaCl}$

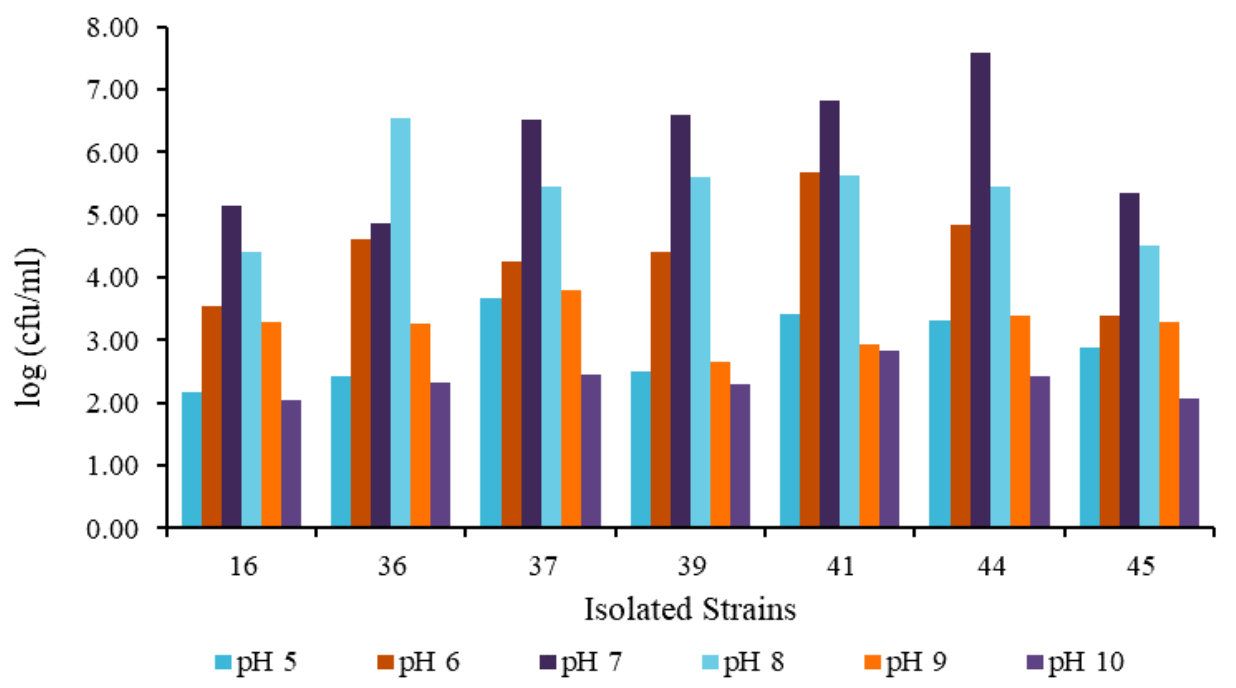

Fig. 3. Viable bacterial count of selected isolates at different $\mathrm{pH}$ values 


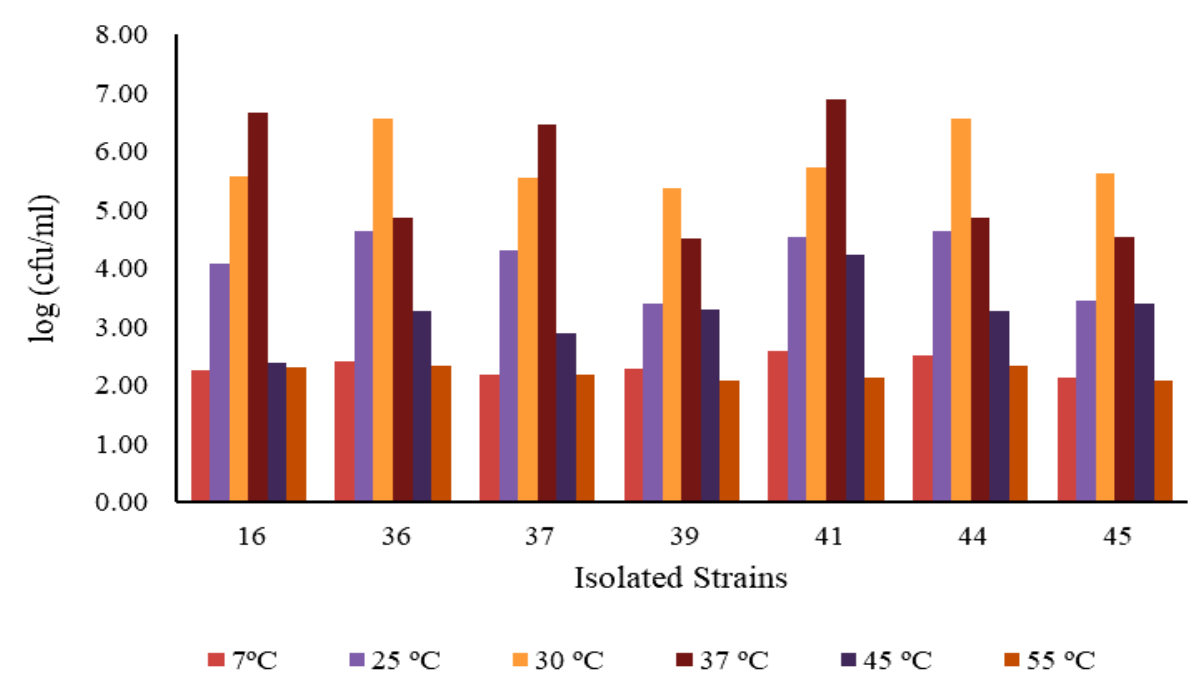

Fig. 4. Viable bacterial count of selected isolates at different incubation temperatures

The obtained results showed that the different concentrations of $\mathrm{NaCl}(0,5,10,15$ and 20\%), different ranges of $\mathrm{pH}(5,6,7,8$ and 9$)$ and different temperatures of incubation $(25,30,37$ and $45^{\circ} \mathrm{C}$ ) could be used for the growth of the selected strains and utilized whey and/or milk permeate for the production of exopolysaccharides.

\section{3- Effect of some growth conditions on EPS production from selected isolates}

Several studies have revealed that whey can be used as a fermentation medium to produce
EPS using different strains (Pantazaki et al 2009, Mozzi, et al 2001).

Data presented in Figs. (5), (6) and (7) indicate that the optimum concentration of $\mathrm{NaCl}$ was $10 \%$ to all the selected strains except strains No. 36 and 39 was $15 \%$. While grown at $\mathrm{pH} 7$ give the best quantity of EPS for all the studied strains except strains No. 36 and 45 was $\mathrm{pH}$ 8. The optimum incubation temperature was $37^{\circ} \mathrm{C}$ for all the selected strains except strain No. 36 .

The previous result show that strains No. 16, 37 and 41 were the best strains in EPS production from whey as it appears in Fig (8).

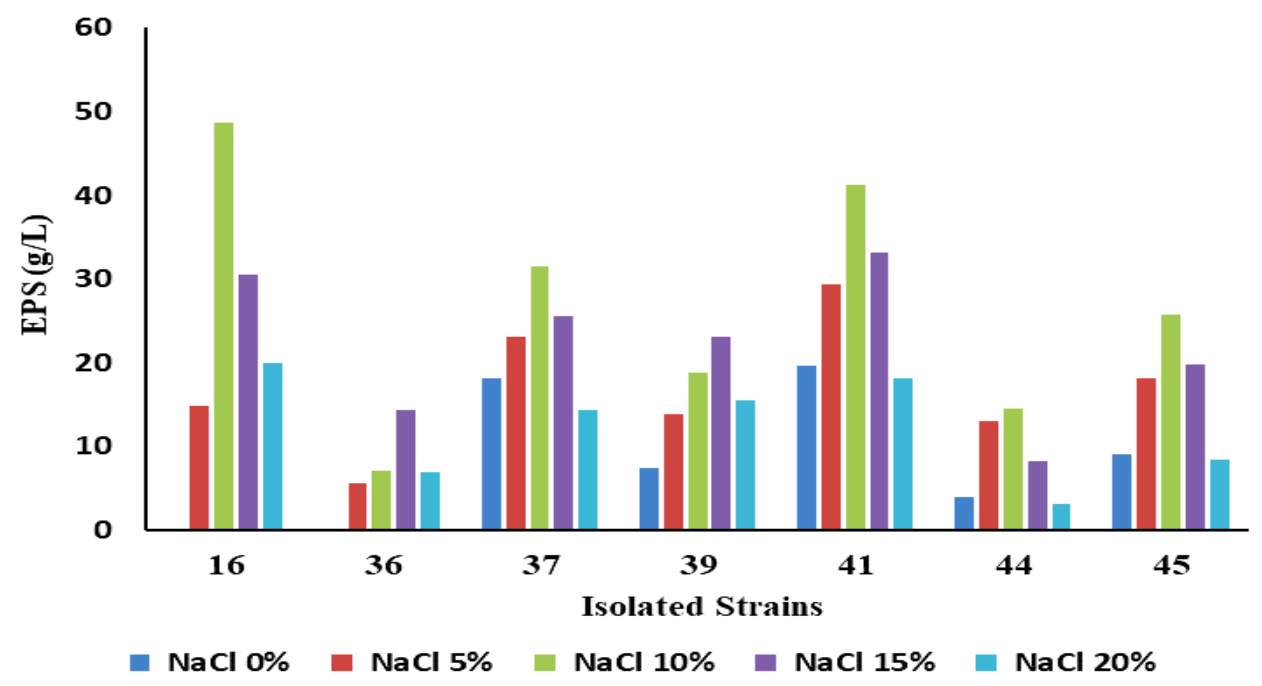

Fig. 5. Production of EPS from selected isolates grown on whey at different concentrations of $\mathrm{NaCl}$. 


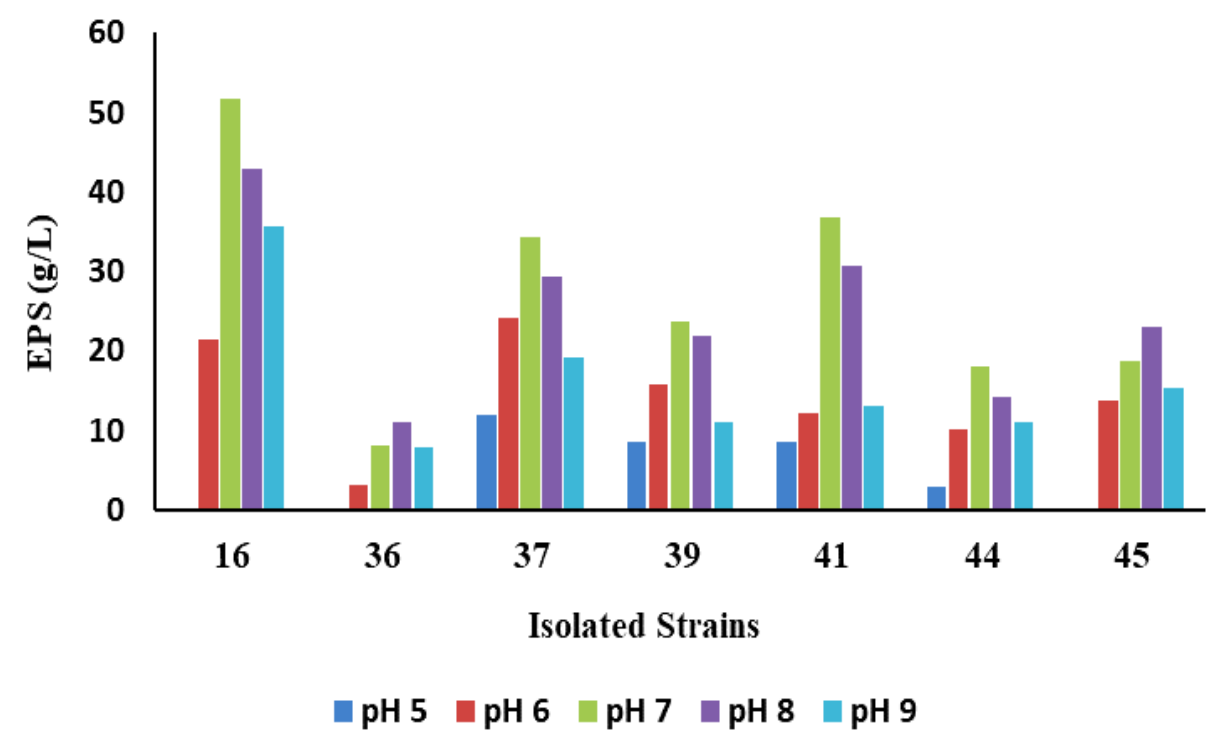

Fig. 6. Production of EPS from selected isolates grown on whey at different $\mathrm{pH}$ values

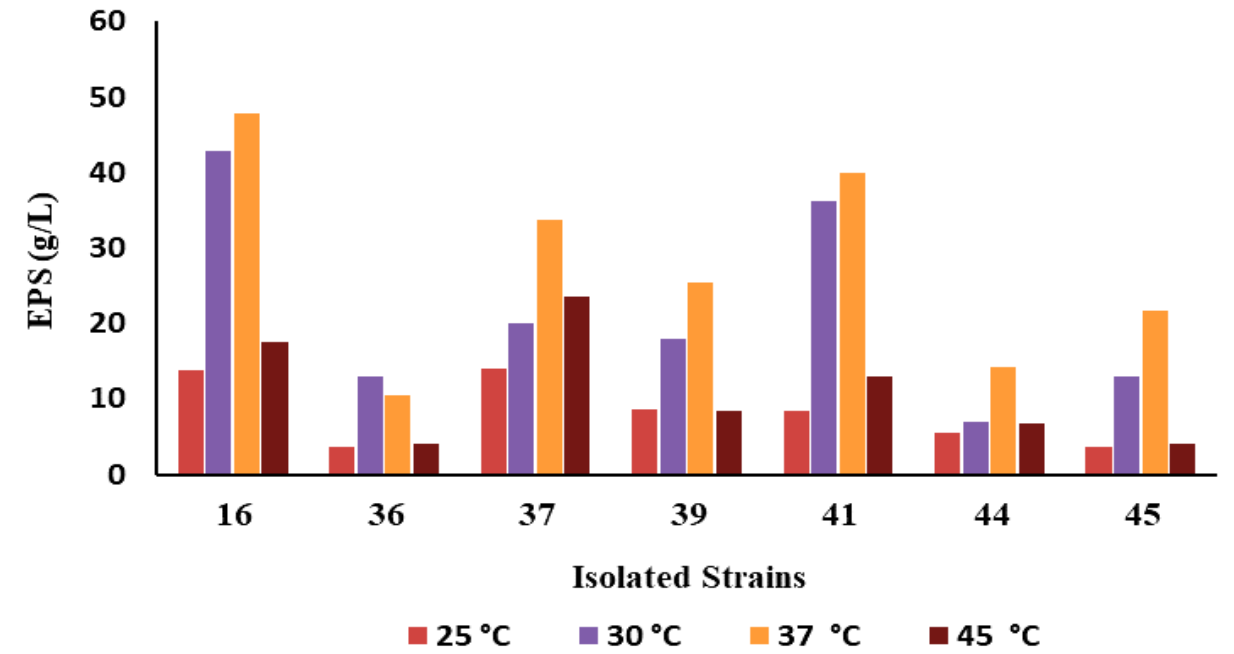

Fig. 7. Production of EPS from selected isolates grown on whey at different incubation temperatures
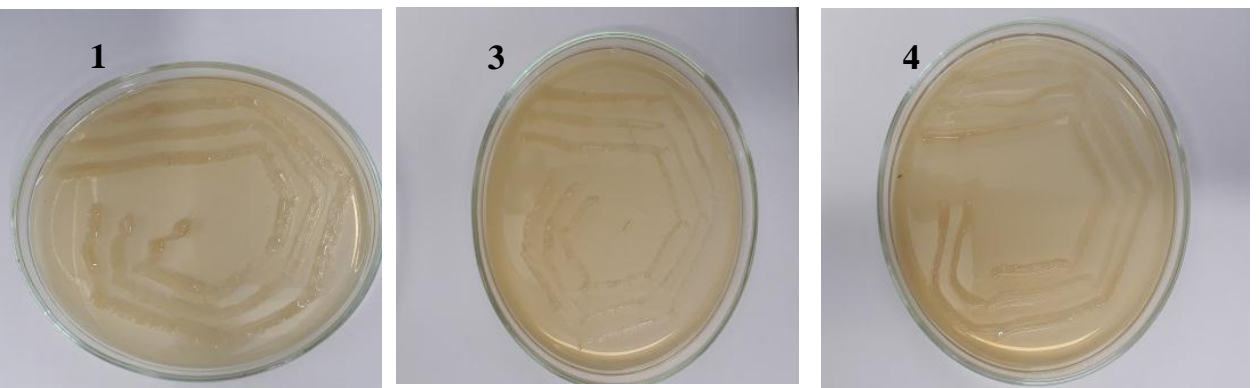

Fig. 8. Mucous colonies of isolated strains on whey medium 

from whey and milk permeate

The effect of $\mathrm{NaCl}$ concentrations, $\mathrm{pH}$ and incubation temperatures on the production of EPS from selected isolates grown on milk permeate was illustrated in Figs. (9), (10) and (11). The obtained results show that the strains No. 16, 37 and 41 were also the best strains in the EPS production when grown on milk permeate. Therefore, these three strains were selected to produce EPS from whey and milk permeate.

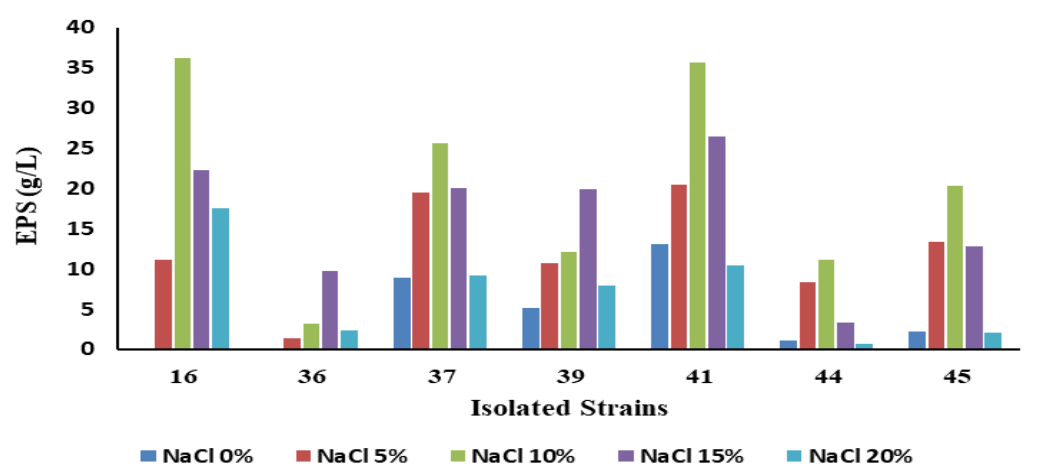

Fig. 9. Production of EPS from selected isolates grown on milk permeate at different concentrations of $\mathrm{NaCl}$.

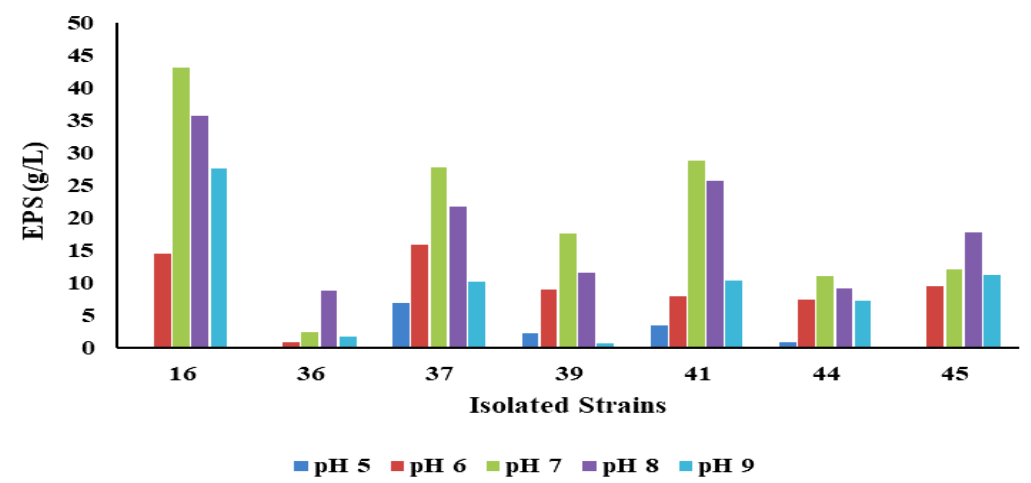

Fig. 10. Production of EPS from selected isolates grown on milk permeate at different $\mathrm{pH}$ values

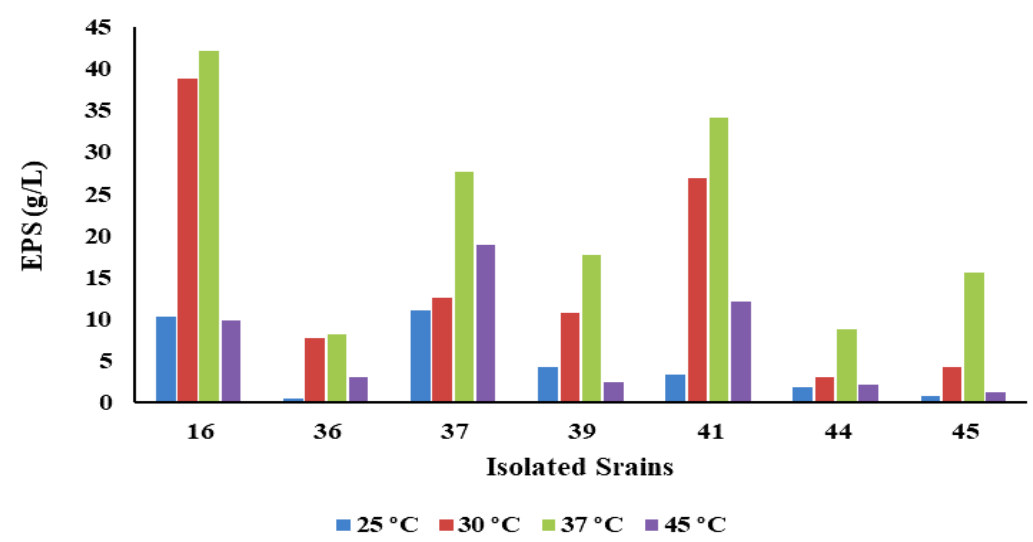

Fig. 11. Production of EPS from selected isolates grown on milk permeate at different incubation temperatures. 
4- Identification of selected isolates (No. 16, 37 and 41)

Table (2) shows the taxonomical characteristics of the strains 16,37 and 41 . While
Fig's (12, 13 and 14) represent the molecular identification of the isolated strains 16,37 and 41 respectively, based on the partial sequence of $16 \mathrm{~S}$ rRNA gene.

Table 2. Taxonomical characteristics of the strains No. 16, 37 and 41

\begin{tabular}{|c|c|c|c|}
\hline \multirow{2}{*}{ Property } & \multicolumn{3}{|c|}{ Characterization } \\
\hline & 16 & 37 & 41 \\
\hline Gram stain & $\mathrm{G}^{+}$ & $\mathrm{G}^{+}$ & $\mathrm{G}^{+}$ \\
\hline Shape & Rod & Rod & Rod \\
\hline Sporulation & + & + & + \\
\hline Motility & - & + & + \\
\hline Nitrate reduction & + & + & + \\
\hline VP (Voges-Proskauer) test & + & + & + \\
\hline Citrate utilization & + & + & + \\
\hline Acid from D-glucose & + & + & + \\
\hline Acid from D-xylose & + & + & + \\
\hline Acid from mannitol & + & + & + \\
\hline Urease production & - & + & + \\
\hline Indole formation & + & + & + \\
\hline Catalase test & + & + & + \\
\hline Oxidase test & + & + & + \\
\hline Lysine decarboxylase & - & + & + \\
\hline Ornithine decarboxylase & - & - & - \\
\hline $\mathrm{H}_{2} \mathrm{~S}$ Production & - & - & - \\
\hline ONPG (hydrolysis of $\beta$-nitrophenyl- $\beta$-d-galactopyranoside) & + & + & + \\
\hline TDA (production of indolpyruvate) & + & + & + \\
\hline
\end{tabular}
+ : positive
-: negative

95 Alteribacillus persepolensis strain HS136 16 S ribosomal RNA gene, partial sequence

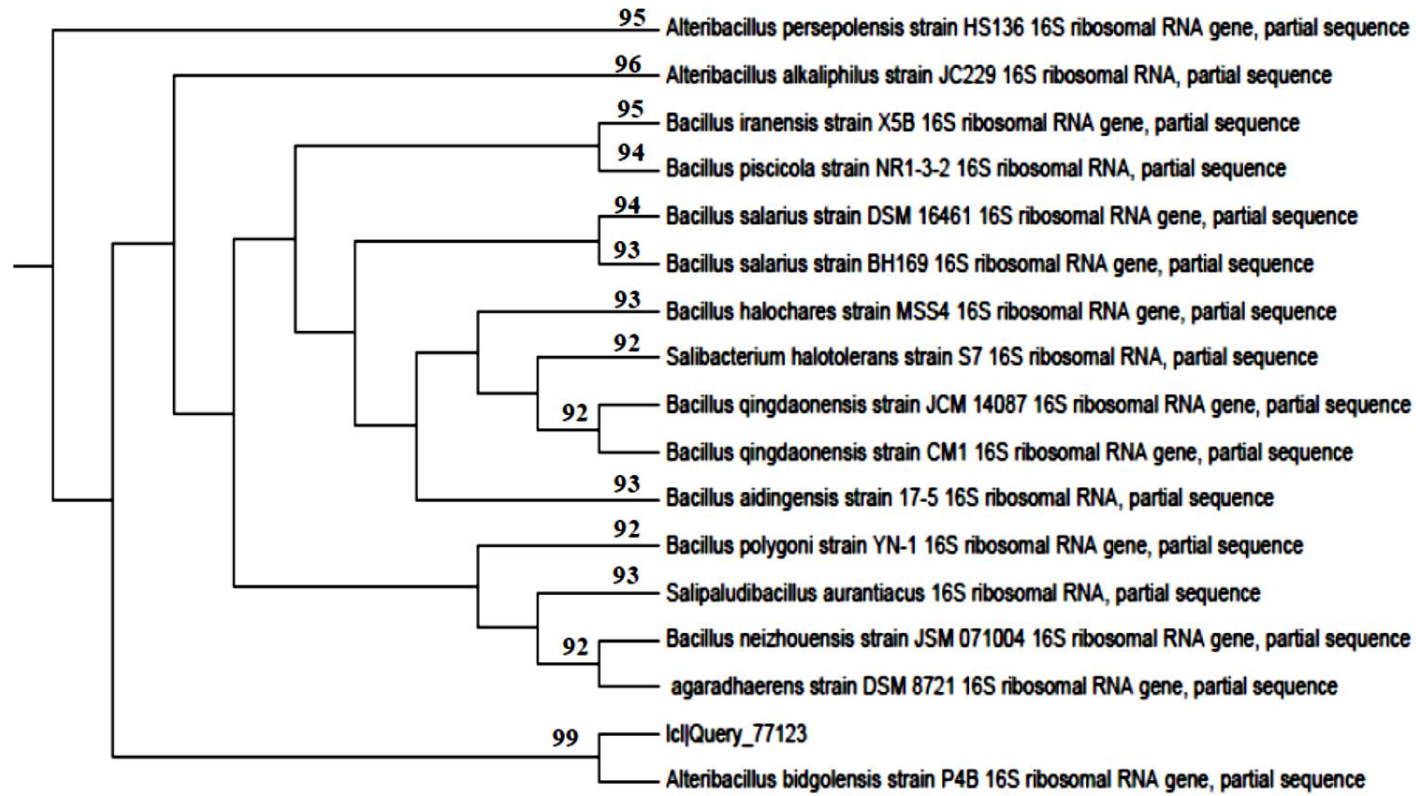

Fig. 12. Phylogenetic tree based on $16 \mathrm{~S}$ rRNA sequences showing the position of strain 16 among its closely related organisms

AUJASCI, Arab Univ. J. Agric. Sci., 27(2), 2019 


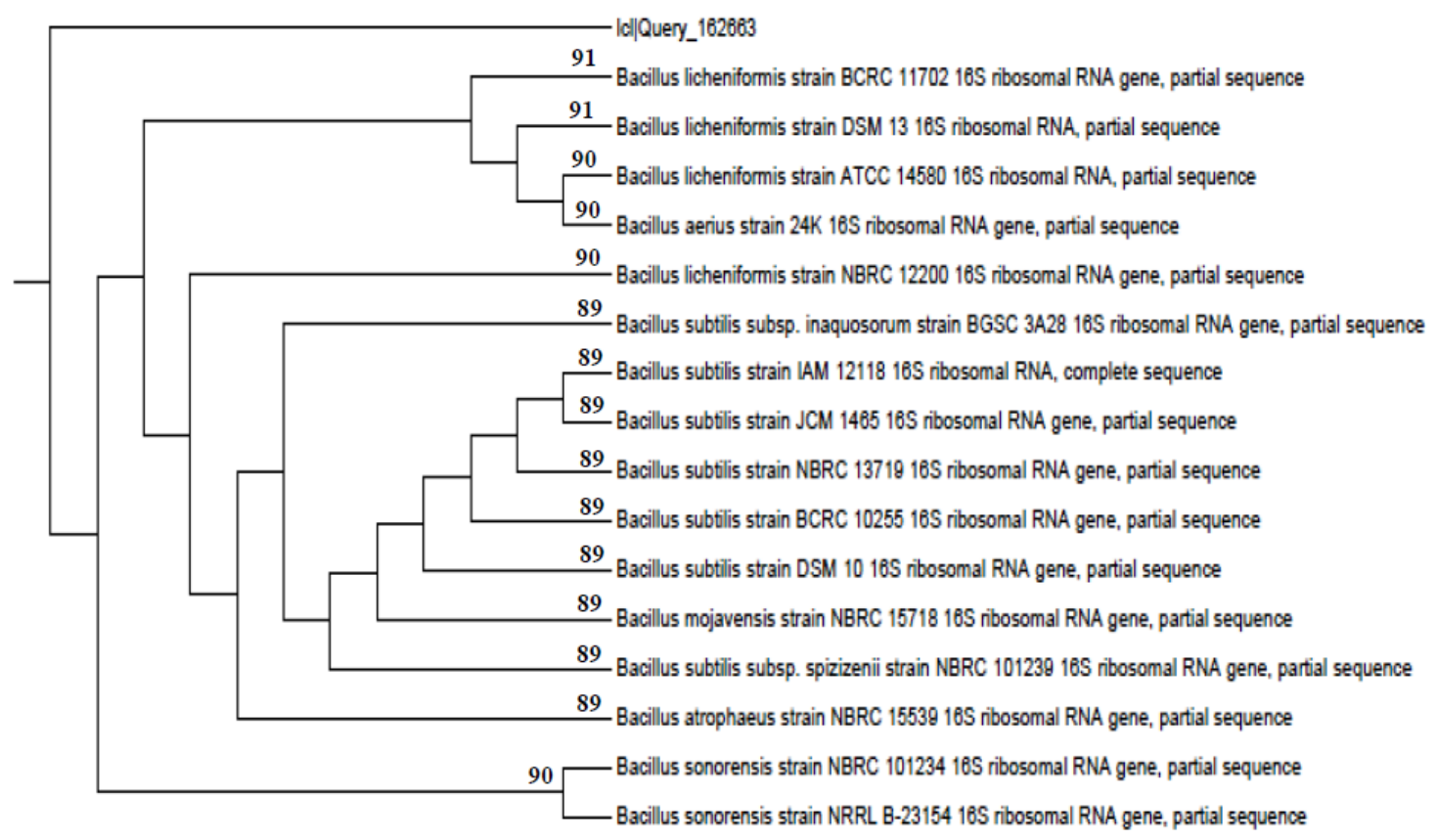

Fig. 13. Phylogenetic tree based on 16S rRNA sequences showing the position of strain 37 among its closely related organisms

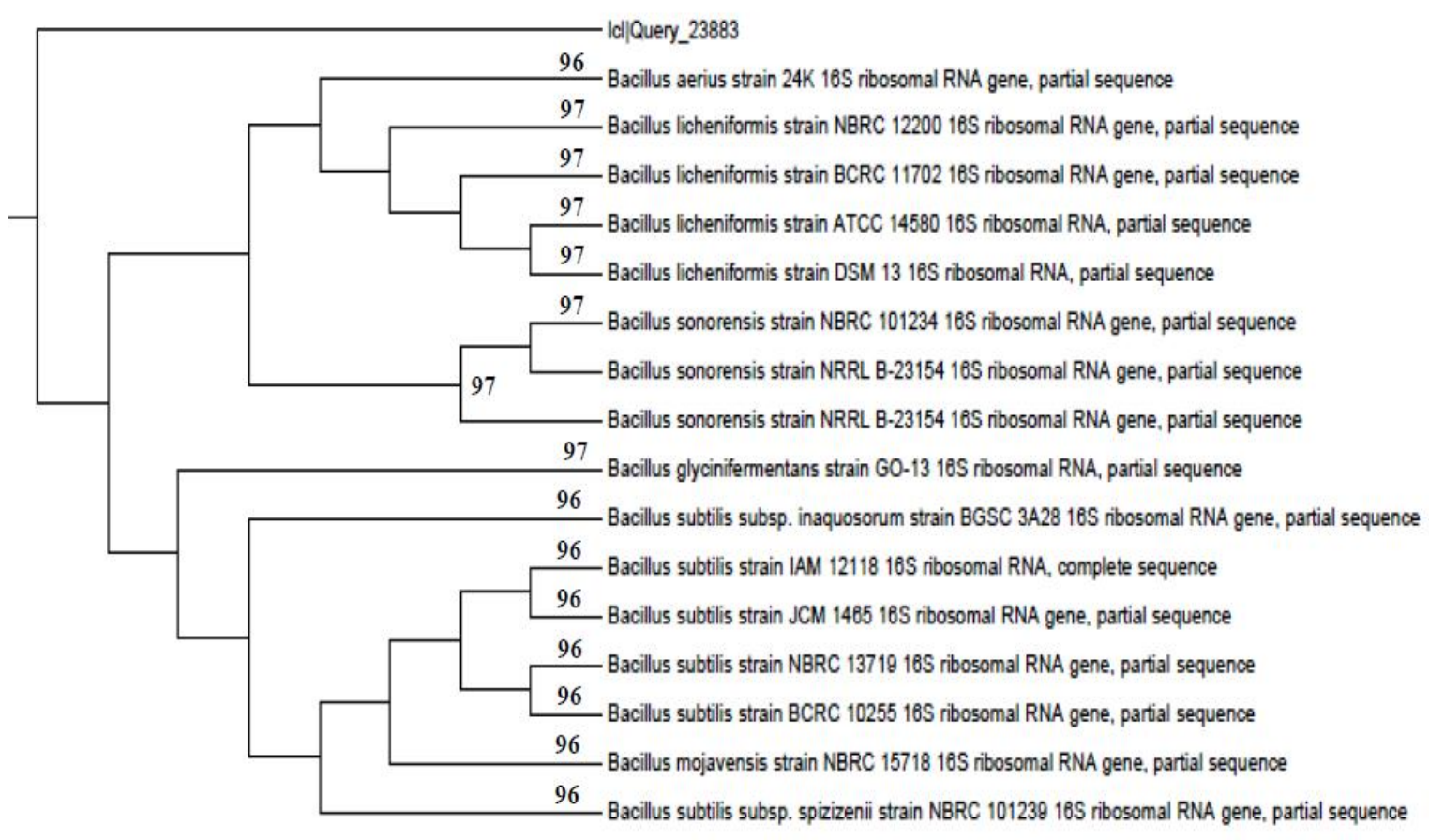

Fig. 14. Phylogenetic tree based on 16S rRNA sequences showing the position of strain 41 among its closely related organism 
In conclusion, the isolated strains are identified as follow:

- 16: Alteribacillus bidgolensis strain P4B 16S ribosomal RNA gene, partial sequence - 37: Bacillus licheniformis strain DSM 13 16S ribosomal RNA, partial sequence

- 41: Bacillus licheniformis strain DSM 13 16S ribosomal RNA, partial sequence

These results are in a contrast with those reported by (Song et al 2011) for B. licheniforms which produced large amounts of EPS.

The genus Alteribacillus belongs to the family Bacillaceae within the phylum firmicutes. The genus includes two species with validly published names at the time of writing. The genus Alteribacillus was first proposed by Didari et al (2012) with Alteribacillus bidgolensis as the type species. The other species of the genus, Alteribacillus persepolensis (Didari et al 2012), was previously classified as Bacillus persepolensis. The common characteristics of members of the genus Alteribacillus are: Gram-stain-positive, aerobic, rod shaped, endospore-forming, oxidase- and catalase-positive, chemo-organotrophic, moderately halophilic. Members of the genus Alteribacillus were isolated from sediment/water samples of hypersaline habitats (Didari et al 2012; Amoozegar et al 2009).

\section{REFERENCES}

Amoozegar M. A., Sanchez-Porro C., Rohban R., Hajighasemi M. and Ventosa A. 2009. Bacillus persepolensis sp. nov., a moderately halophilic bacterium from a hypersaline lake. Int. J. Syst. Evol. Microbiol. 59, 2352-2358.

Bejar V., Llamas I., Calvo C. and Quesada E. 1998. Characterization of exopolysaccharides produced by 19 halophilic strains included in the species Halomonas eurihalina. J. Biotechnol. 61, 135-141.

Biolog D.B. 2009. MicroStation ${ }^{\mathrm{TM}}$ System/MicroLog. Hayward, CA 94545, U.S.A.

Fox P.F., Guinee T.P., Cogan T.M. and McSweeney P.L.H. 2017. Whey and Whey Products, In: Fundamentals of Cheese Science. $2^{\text {nd }}$ Ed. pp. 755-767, Springer, New York, U.S.A.

James C.S. 1995. General food studies, In Analytical Chemistry of Foods, $1^{\text {st }}$ Ed. pp. 137-170, Springer - Science + Business Media, B.V. UK.

Martinez-Checa E., Calvo C., Caba M.A., Ferrer M.R., Bejar V. and Quesada E. 1996. Efecto de las condiciones nutricionales en la capaci- dad viscosizante y emulgente del biopolimero V2-7. Microbiologia SEM. 12, 55-60.

Maryam Didari, Amoozegar M.A., Maryam Bagheri, Schumann P., Cathrin Spröer, Cristina Sánchez-Porro and Ventosa A. 2012. Alteribacillus bidgolensis gen. nov., sp. nov., a moderately halophilic bacterium from a hypersaline lake, and reclassification of Bacillus persepolensis as Alteribacillus persepolensis comb. nov. Int. J. Syst. Evol. Microbiol. 62, 2691-2697.

Mesbah N.M., Abou-El-Ela S.H. and Wiegel J. 2007. Novel and unexpected prokaryotic diversity in water and sediments of the alkaline, hypersaline lakes of the Wadi El Natrun, Egypt. Microb Ecol. 54, 598-617.

Morris G.A. and Harding S.E. 2009. Polysaccharides, Microbial. In: Encyclopedia of Microbiology $3^{\text {rd }}$ Ed. pp. 482-494, Elsevier, Amsterdam.

Mozzi F., Torino María Inés and Font De Valdez G. 2001. Identification of exopolysaccharideproducing lactic acid bacteria. in: food microbiology protocols, Spencer, John F.T., Ragout de Spencer and Alicia I. (eds.), pp. 183-190, Humana Press Inc. Totowa, New Jersey, U.S.A.

Nadiah S. Abd Samad, Amid A., Jimat D.N. and Ab. Shukor, N.A. 2017. Isolation and identification of halophilic bacteria producing halotolerant protease. Sci. Heritage J. 1(1), 7-9.

Pantazaki A.A., Papaneophytou C.P., Pritsa A.G., Kyriakides M.L. and Kyriakidis D.A. 2009. Production of polyhydroxyalkanoates from whey by Thermus thermophilus HB8. Process Biochemistry. 44, 847-853.

Ruas-Madiedo P. and de los Reyes-Gavilan C.G. 2005. Methods for the screening, isolation and characterization of exopolysaccharides produced by lactic acid bacteria. J. Dairy Sci. 88, 843-856.

Song Y.R., Song N.E., Kim J.H., Nho Y.C. and Baik S.H. 2011. Exopolysaccharide produced by bacillus licheniformis strains from kimchi. J. Gen. Appl. Microbiol. 57, 169-175.

Tombs M. and Harding S.E. 1998. An introduction to polysaccharide biotechnology. pp. 329-332, Taylor and Francis, London, UK.

Welman A.D., Maddox I.S. and Archer R.H. 2003. Screening and selection of exopolysaccharide-producing strains of lactobacillus delbrueckii subsp. bulgaricus. J. Appl. Microbiol. 95, 1200-1206. 
مجلة اتحاد الجامعات العربية للعلوم الزراعية ، جامعة عين شمس ، القاهرة ، مصر

مجلا(27)، عدد(2)، 1501-1491، 2019

Website: http://ajs.journals.ekb.eg

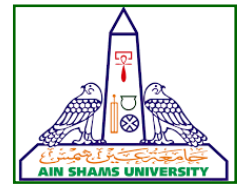

1501

\title{
عزل وتعريف البكتريا المحبة للملوحة المنتجة للسكريدات العديدة الخارجية من الثرش وراشح اللبن
}

[123]

\begin{abstract}
امل عبد الله حجازى" - محمد عبد الرازق النواوى - على عبد العزيز على- يحيى عبد العظيم السمرجى

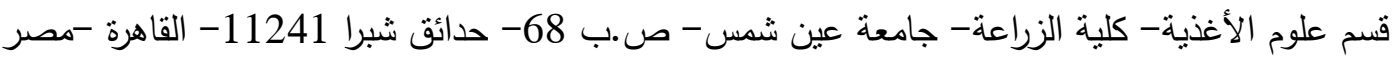

*Corresponding author: amal hegazy@agr.asu.edu.eg

Received 10 May, 2019

Accepted 9 June, 2019

أنثارت النتائج إلي أن الظروف المنلي للإنتاج كانت 10 \% كلوريد صوديوم، الرقم الهيدروجيني 7 ودرجة لإنتاج

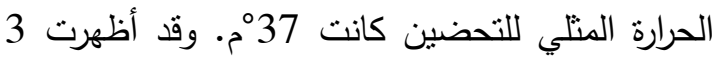
سلالات أعلي إنتاجية للسكريدات العديدة. تم تعريف هذه السلالات بإستخدام طريقتين للتعريف الطريقة لإنة

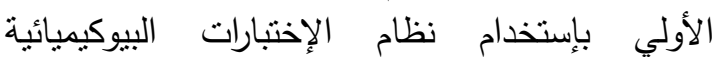

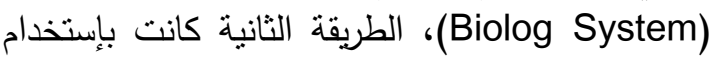
نظام 16S rRNA. وقد عرفت السلالات علي إنها Bacillus , Alteribacillus bidgolensis

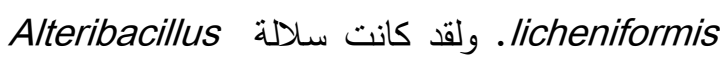
الأعلى في إنتاج السكريدات العديدة

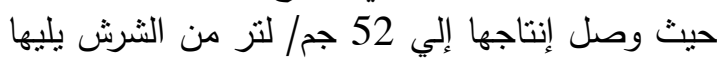
سلالة Bacillus licheniformis بإنتاجية 42 جم/ لرن Alteribacillus لتز . بينما كانت أيضا الأعلي إنتاجيه من راثنح اللبن bidgolensis

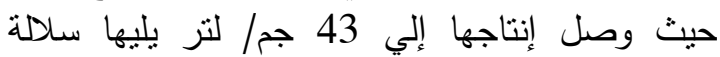
Bacillus licheniformis لذلك توصي الدراسة بإمكانية إنتاج تلك المركبات بإستخدام سلالة Alteribacillus bidgolensis وذلكات الإنة لرفع القيمة الأقتصادية للمخلفات السائلة لصناعة الجبن وتقليل العبئ البيئي.

الكلمات الدالة: البكتريا المحبة للملوحة، السكريدات

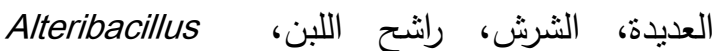
bidgolensis, Bacillus licheniformis.

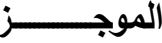

الهدف من البحث دراسة مدي إمكانية إستخدام شرش اللبن المملح وراشح اللبن بغرض إنتاج سكريدات عديدة

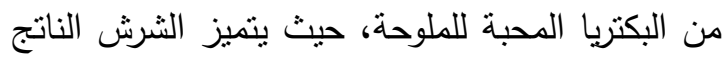

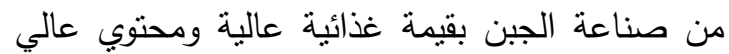

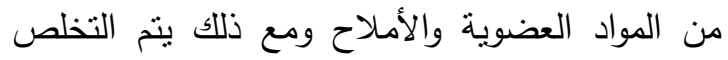

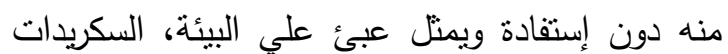

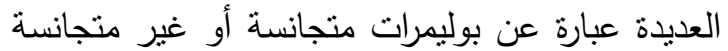

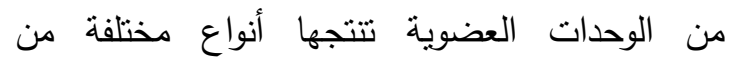
الكائنات الحية الدقيقة ولقد زاد الأهتمام بها نظرا

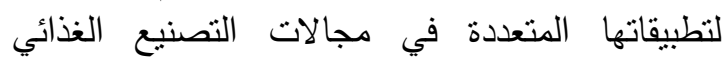

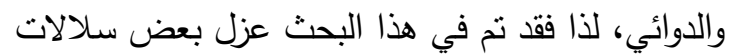
البكتريا التي لها القدرة علي إنتاج السكريدات العديدة التهن

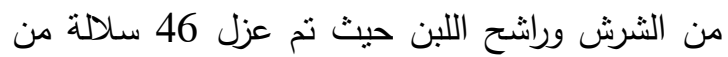

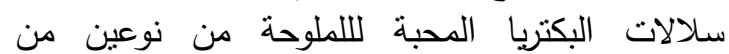

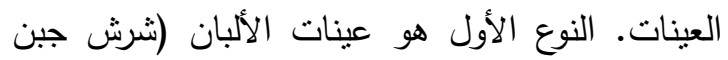
براميلي، مش) ، أما النوع الثاني فكان عينات من الإنيات النيان

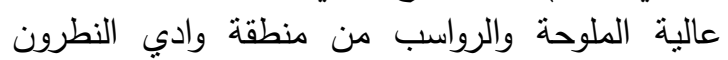

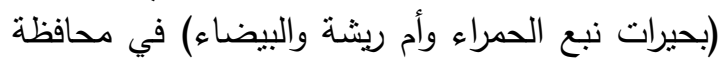

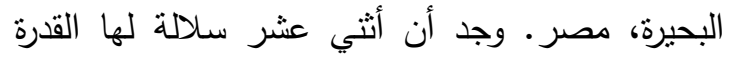

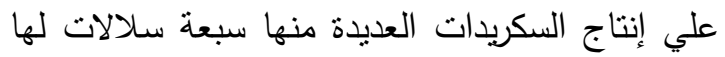

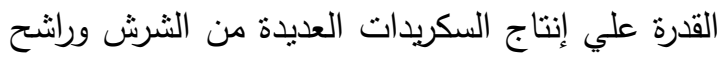

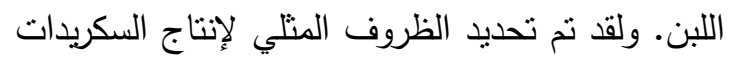

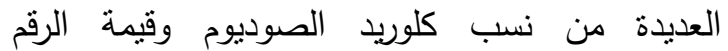
الهيدرجيني ودرجات حرارة التحضين المختلفة. حيث تحكيم: ا.د يوسف مرسي الكناني ا.د باهر عبد الخالق عفت الد برني 